\title{
A Study of Potential Load Bearing Masonry (LBM) System in Malaysia Construction Industry
}

\author{
N.A. Ramli ${ }^{1}$, C. S. Abdullah ${ }^{2}$, M.N. Mohd Nawi ${ }^{3}$ \\ ${ }^{1,2,3}$ School of Technology Management and Logistics, Universiti Utara Malaysia, 06010 Sintok, \\ Kedah, Malaysia.
}

\begin{abstract}
To overcome the problems in increasing of material prices, land prices, shortage of skilled workers, equipping low cost housing demands and maintained the cost of the constructing at an affordable price, there is a need to find the alternative solution for constructing method. The use of the load bearing masonry system (LBM) has been identified as a sustainable and an effective alternative method for the construction industry. The system offers several advantages in term of cost and speed of the construction, durability, strength, environmentally friendly practices and aesthetic qualities. Despite these advantages, unfortunately, this system has not been widely used in Malaysia compared to reinforced concrete (RC) frame construction. Therefore, this paper aims to discuss the advantages and potential of the system implementation to Malaysia construction industry in the future.
\end{abstract}

\section{Introduction}

Housing is one the most important needs of the human basis and demands of the houses increase through the growth of population. To meet market demand of the affordable housing especially for lower income group, government under the 10th Malaysia Plan (2011-2015) committed to build 38,000 units low cost housing under Program Perumahan Rakyat (PPR). Unfortunately, there are delays in the construction of some of the projects as a results of escalation of material prices, shortage material during construction and shortage in supply of labor (1); [1]. These factors have led to frequent demands of low cost housing which seems difficult to achieve (1); [1].

Additionally, the increasing land prices also contributed to these inadequate demands. According to Mooi [2], the price of land in ten year estimate increases for about 0.6 percent in Johor and 5.5 percent in Kuala Lumpur states in Malaysia. Therefore, the increasing price is found to be influenced by insufficient lands, speculation activities in land industry which shows the prices of land will increase in the future especially in urban areas.

Because of these reasons, the alternative construction methods need to be introduced to overcome the problems. A load bearing masonry system is one of a good alternative in terms of their advantages which reduced of construction cost, time and its durability, together with aesthetics and flexibility [3] while compare to the conventional RC frame system. Moreover, a load bearing masonry system was introduced in the early time of civilizations. With the advancement in research and development, load bearing masonry has been widely accepted and used for housing and building in the developed countries like United States and Europe. 


\section{Historical and Development of Masonry}

Masonry is the simplest technique for the building construction and made from collective units of bricks, stones, concrete and blocks in making a wall. Masonry buildings portray the great works of architecture in the world, where many buildings have been built using masonry technique giving it a heritage building.

Many types of materials have been used for masonry units. In the early civilization, the sun dried mud bricks were used by the people of Mesopotamia for their shelter and temples. Moreover, the Egyptians used the stones for their temples and pyramids. Today, the common masonry constructed from the use of clay, concrete, soil and calcium silicate respectively.

Masonry structures have been used in the earlier century from the smallest to huge building, infrastructural and monument. Pyramid of Egypt, the Towel of Babel in Mesopotamia and Mohenjo Daro in the Indus valley, Holy of Kaabah and Great Wall of China have been considered part of several constructions in the world that used masonry structures.

As cheaper and early materials of construction, the masonry is widely used in the developed countries like United States and Europe. The masonry building is built based on graphical methods or simple calculation as cantilever wall, without shear wall and lead to the increased thickness from top to bottom. In the late of the 19th century, masonry began to lose its priority among the material of construction. The building began to choose the structure frame from steel and reinforce concrete to replace the masonry structure. An example of the final masonry structure was built in the year 1891, the Monadnock Building with sixteen (16) stories in Chicago was considered as the final triumph of traditional masonry structures that was designed by John Root with $1.82 \mathrm{~m}$ thickness of the walls [4].

\section{Modern Masonry Structural}

A modern concept of masonry buildings has been introduced in many countries in the middle of the 20th century, making use of the design that is based on shear walls due to the resistance of longitudinal walls, transverse walls and slab against horizontal action [5]. This is because the walls could be used both in compression and shear to resist the wind loading in any direction and provide possibility of making the buildings with high number of floors. This principle is moderated the thickness of walls and built in zones of low seismic hazard and widely spread in the Europe, where there are many load bearing brickwork exceeding ten stories. The example of buildings that used this modern system can be found in Switzerland with 18 stories load bearing building supported on relatively thick walls $127 \mathrm{~mm}$ to $254 \mathrm{~mm}$ was built in 1957 . The design of this building was determined by the requirement of the thermal insulation rather than a structural requirement [6]. Besides that, this type of construction has become norm all over the world with many examples; 12 stories blocks of flats in Birmingham United Kingdom, 17 stories Park Mayfair East Building in Denver Colorado and 11 stories Muskegon Retirement Apartment in Muskegon Michigan.

Recently, this system has come with innovative design through the research and development. According to a study by Mosele et al. [7], the innovative systems for load bearing masonry and nonload bearing masonry wall are based on the advancement of vertical reinforcement and fastening of mortar, concrete block together with integration with special clay and concrete block. Additionally, a study by Lourenco et al. [5] emphasized that alternative replacement reinforced concrete structures are confined lightweight concrete masonry which reinforced hollow concrete masonry. The researches have solved the remaining technical problems and provided modern design methods for seismic areas. This innovative design gives several advantages and they are; new possibilities for masonry, more 
economical construction and maintenance, quality increase for masonry wall, crack-free and earthquake resistant constructs.

\section{Masonry Structural in Malaysia}

In Malaysia, the used of masonry was found more than 350 years ago during the settlement of the Portuguese in Melaka. The Al-Formosa is the example of masonry building heritage that left by them. Then, brick masonry are widely implemented in Tanah Melayu and continued by British. The office and middle class residential are the example of the buildings that were built by the British. Pursuing this further, a modern of masonry construction was initiated by the British. The buildings were found located at Harvard Estate at Gurun and TUDM quarters at Tok Jalai, Jitra [8][9]. Unfortunately many of these buildings have been demolished as a result of the development brought by the government.

For the block materials, it was introduced after independent mainly in housing projects. Example of housing project was using a hollow block of low cost houses at Taman Sri Kemuning, Jitra in year 1970, Setapak Jaya Housing Estate in Setapak in 1978 and the Selayang Utara and Selayang Selatan in 1979 [8][9].

Some of the buildings using a masonry system still around gazette as 'national heritage' in such Bangunan Sultan Abdul Samad in Kuala Lumpur were built in year 1894, Hospital Tun Aminah in Johor Bharu and Bagunan Federated Malay States Railways.

Due to the excellent record in overseas and local, this system had been approved and gazette under the Uniform Building by- Law in 1989. In 1994, the low cost housing project at Chembong Negeri Sembilan were using this system and won the prestigious Prime Minister's Award that organized by Jabatan Perumahan Negara. Since that, a few numbers of housing projects using the load bearing masonry system have been reported. Unfortunately, the usages of the masonry structural are less popular in Malaysia country despite the associated advantages to this structure.

\section{Load Bearing Masonry Definition}

Load bearing masonry system has been applied until now is based on rational engineering design. Load bearing masonry is a concept where the floors and walls work together as a system, each giving support to others [10]. In the simple definition of load bearing system, the system was designed to support the building loads by the roof, upper floor slabs, dead load and lateral loads, such as wind and soil pressure. Indeed, beams, columns, stairs and foundation can also build with masonry. Generally, there are three types of structural masonry namely, plain masonry or unreinforced masonry, reinforced masonry and pre stressed masonry.

\section{The Advantages of Load Bearing Masonry System}

The load bearing masonry wall is the oldest technique of construction and widely used in the developed countries. With the development of the reinforced and pre-stressed masonry structure, this system is becoming popular for the large span building in such factories, commercial premises and sports center. Load bearing masonry system offers several advantages compared to the conventional reinforced frame system in terms of cost, speed of construction and design.

\subsection{Economic (cost saving)}

Admittedly, load bearing masonry could provide 10 to 20 percent saving from the total building cost compared to a conventional RC building. These savings achieved by reducing the use of 
reinforced concrete, more economic foundation designs due to uniform load, more efficient roof design and using flat floor construction [11].

Additionally, as reported by Sinha [4], the construction cost saved about 10 percent in Europe over than other forms of construction method and 7 to 9 percent cost savings per square foot per floor in the United States. Meanwhile, in the United Kingdom the used of load bearing masonry system saved about 38 percent of the construction cost.

For the construction process, this system does not require any expensive tool or machine and expensive plan, only skilled workers were needed in laying the number of bricks or blocks [12],[3]. In other hand, the system doesn't have any intensive period for the preparation or fabrication of advance method in beginning of the construction. Since that, it is can reduce the cost of labors and methods.

\subsection{Construction (reduce speed of construction)}

For the speed of the construction, the load bearing system provided 30 to 40 per cent of the saving construction time. These achieved by eliminating the concrete framework, very quick start up of wall construction and continuous construction due to rapid strength gained from the brickwork [11]. For the reinforcement building, the works would have waited until the cast concrete gain enough strength before formwork dismantled. Structural masonry does not require large of scaffolding for the construction work where the units of block or brick were laid seem like 'LEGO' concepts and the completion of the construction is about half of the frame building structural Sinha [4] and this system is ease to assemble in the construction site.

\subsection{Design}

From the designers view, the usage of this system related to durability and flexibility. The durability may be expected serviceable for many decades due to appropriate materials selection. For flexibility from the architectural viewpoint, it offers advantages in terms of greater flexibility of plan form, where the detailing and layout are simple and flexible due to the repetitive floor arrangement. This system has the versatility of the texture and pattern where it offers an unlimited colour, texture and patterns of masonry units [4].

In the European Countries the structure masonry walls is carried out according to the national code of practices, where in the United Kingdom the British Standard (BS 5621) or Euro code 6 are used for design. Structural design based on both of these codes is based on limit state principles, safety being assured by the use of characteristic value of load and material strength together with partial safety factors, applied as a multiplier to load and as a divisor to strength [3].

Load bearing masonry system is one of the construction methods that contribute to the sustainable construction through their materials used. According to the El - Adaway et al. [13], brick contribute to the sustainable through three important factors which are: made of brick, manufactured and the used of brick and the detailed as followed:

a. Bricks were made from the natural resources in such clay and shale

b. Bricks manufacturing located in close to mine. It can incorporate waste products in term reduce energy, reduce water use and gas emission and other wasters of fuel

c. Brickwork can provide acoustic comfort, thermal comfort, and good indoor air quality and fire resistance

Brickwork also meets the requirement of many certificated rating systems in the area of development of density, storm water management, heat island effect, improve energy performance, construction waste management and low maintenance in overseas respectively as reported by BIA [14]. Consequently, the list of advantages of the load bearing could be summarized as the following Table 1. 


\section{Conclusion}

Since the advantages and the implementation widely spread in the overseas, the government mainly has to take initiates to promote the usage of this system in Malaysia construction industry. Implementation of this system can be great platform to improve the method and demands for the housing projects. In other hand, this system is an effective approach in order to enhance the level of productivity, effectiveness and efficiency of the industry business and housing industry respectively.

Table 1.The advantages of load bearing masonry system in construction industry

\begin{tabular}{|c|c|c|}
\hline No & Advantages of LBM system & Authors \\
\hline 1 & $\begin{array}{l}\text { Economic } \\
-\quad \text { (reduce cost of construction })\end{array}$ & $\begin{array}{l}\text { (Nasly and Yassin 2009; } \\
\text { Lourenco et al., 2008; Sinha, } \\
\text { 2002; Hendry 2001; Majid, 1997) }\end{array}$ \\
\hline 2 & $\begin{array}{l}\text { Construction } \\
-\quad \text { (enhance speed of construction) }\end{array}$ & $\begin{array}{l}\text { (Nasly and Yassin 2009; } \\
\text { Lourenco et al., 2008; Sinha, }\end{array}$ \\
\hline 3 & $\begin{array}{l}\text { Design } \\
\text { - Complied with the code and } \\
\text { practices }\end{array}$ & $\begin{array}{l}\text { 2002; Majid, } 1997 \\
\text { (Hendry 2001) }\end{array}$ \\
\hline & $\begin{array}{ll}\text { - } & \text { Simplicity of design and } \\
\text { flexibility } \\
\text { - }\end{array}$ & $\begin{array}{l}\text { (Sinha 2002) } \\
\text { (El- Adaway et al., 2011; BIA, } \\
\text { (Mos) } \\
\text { and Thallon 2006) }\end{array}$ \\
\hline \multirow[t]{2}{*}{4} & $\begin{array}{l}\text { Without expensive plant and } \\
\text { machines }\end{array}$ & (Hendry, 2001) \\
\hline & $\begin{array}{l}\text { Products } \\
\text { Quality of permanence, solidity, } \\
\text { fire resistance, excellence in } \\
\text { texture and pattern. }\end{array}$ & $\begin{array}{l}\text { (Allan and Thallon 2006; Mehta } \\
\text { et al., 2013) }\end{array}$ \\
\hline
\end{tabular}

\section{References}

1. Sambasivan, M. \& Soon,Y.W., (2007). Causes and effects of delays in Malaysia construction industry, Journal of Project Management, vol. 25, pp 517-526

2. Mooi, V.L.G. (2012). Harga hartanah mula meningkat selepas 2009, Utusan Malaysia (bisness). September 2012

3. Hendry, A.W. (2001). Masonry walls: material and construction. Journal of Construction and Building Materials. vol.5, pp 323-330

4. Sinha, B.P. (2002). Development and potential of structural masonry, Seminar on masonry wall, Porto

5. Lourenco, P.B., Vasconcelos, G., Gouveia, J.P., (2008). Innovation solutions for masonry structures: Conception, testing and application, $5^{\text {th }}$ International Conference (AMCM' 2008), Poland.

6. Brick Industry Association, (2002). The Contemporary Bearing Wall. Technical Notes on Brick Construction.

7. Mosele, F., da Porto, F., Modena, C. Di Fusco, A.,Di Cesare, G., Vasconcelos, G., Haach, V., Lourenco, P.B., Beer, I., Schmidt, U.,Brameshuber, W., Scheufler, W., Shermer, D.C. \& Zilch. 
K.,(2006). Developing innovative systems for reinforced masonry walls, Proceeding 7th International Masonry Conference, London,pp.530-541

8. Abdullah, C.S, Zulhumadi, F. \& Othman A.R., (2009). Load bearing masonry construction system - its adoption by the construction industry in Malaysia, Malaysia Construction Research Journal, vol.4 (2), pp 25-39

9. Abdullah, C.S., (2009). Load bearing masonry- its materials, construction and time-dependent properties, Inaugural Professional Lecture, Universiti Utara Malaysia.

10. Brick Industry Association, (1997). Reinforced brick masonry- Material and construction, Technical Notes on Brick Construction.

11. Majid,S., (1997). Loadbearing brickwork methods offers advantahges. Business Times, publication date: 13/01/1997

12. Allen and Thallon, (2006). Fundamentals of residential and construction ( $2^{\text {nd }}$ Edition), United States, John Wiley and Sons.

13. El- Adaway, I., Breakah, T. \& Khedr, S., (2011). Brick and sustainable construction, Integrating Sustainable Practices in the Construction Industry. (ICSDC 2011), International Conference on Sustainable Design and Construction, Kansas City, Missouri

14. Brick Industry Association, (2009). Sustainability and Brick, Technical Notes on Brick Construction 